\title{
Influence of late emerging weeds in glyphosate-resistant corn
}

\author{
Nader Soltani ${ }^{1^{*}}$, Robert E. Nurse ${ }^{2}$, Eric Page $^{2}$, Wesley J. Everman ${ }^{3}$, Christy L. Sprague $^{3}$, \\ Peter H. Sikkema ${ }^{1}$ \\ ${ }^{1}$ University of Guelph Ridgetown Campus, Ridgetown, Canada; *Corresponding Author: soltanin@uoguelph.ca \\ ${ }^{2}$ Agriculture and Agri-Food Canada, Harrow, Canada \\ ${ }^{3}$ Michigan State University, East Lansing, USA
}

Received 20 April 2013; revised 21 May 2013; accepted 5 June 2013

Copyright (C) 2013 Nader Soltani et al. This is an open access article distributed under the Creative Commons Attribution License, which permits unrestricted use, distribution, and reproduction in any medium, provided the original work is properly cited.

\begin{abstract}
Fifteen field trials were conducted from 2009 to 2011 in Ontario, Canada and Michigan, USA to determine how long glyphosate-resistant corn needs to be kept weed-free after emergence to prevent yield loss. Data were separated into two environments based on when yield loss first occurred after glyphosate application. In Environment 1 (4/15 sites) yield was not reduced when corn was kept weed-free until the 4-leaf stage. However, in Environment 2 (11/15 sites) there was no yield loss when corn was kept weed-free up to the 2-leaf stage. The most prominent weeds were velvetleaf, redroot pigweed, common ragweed, common lambsquarters and foxtail species. While later emerging weeds did not necessarily impact corn yield, weeds emerging after the 2- and 4-leaf corn stage likely produced seed that was added to the soil seed bank. Weeds emerging after 6-, 8-, and 10-leaf corn growth stages were small (low biomass/seedlings) and most likely did not reach reproductive maturity. Based on this research, corn must be maintained weed-free up to the 4-leaf stage. Any weeds emerging after that did not influence corn yield.
\end{abstract}

Keywords: Biomass; Density;

Glyphosate-Resistant Corn; Leaf Stage;

Maize; Plant Height; Yield

\section{INTRODUCTION}

Most of the corn produced in Canada is grown in Ontario (nearly 63\%) where growers produce nearly 7.2 million tonnes of grain corn on approximately 822,000 hectares with a farm gate value of more than $\$ 1.3$ billion $[1,2]$. Effective weed control is an important component of profitable corn production. Current troublesome weeds include common lambsquarters (Chenopdium album L.), redroot pigweed (Amaranthus retroflexus L.), common ragweed (Ambrosia artemisiifolia L.), velvetleaf (Abutilon theophrasti Medic.), ladysthumb (Polygonum persicaria L.), wild mustard (Sinapis arvensis L.), annual nightshades (Solanum spp.), and annual grasses such as foxtails (Setarias pp.) [3].

Most of the corn grown in Ontario is glyphosate-resistant which has provided growers with additional weed management options with economic advantages $[4,5]$. Glyphosate-resistant corn was first introduced in Canada in 2001 and the market share has increased steadily over the years. In 2012, about $94 \%$ of the corn hectares in Eastern Canada were planted to glyphosate-resistant hybrids and the percentage is expected to increase in the future [4]. Glyphosate-resistant corn is popular in Eastern Canada as it provides many benefits to growers including excellent crop tolerance, a wide window of herbicide application, broad spectrum weed control, more consistent weed control under various environments, lower cost of weed control, greater yield, and higher net returns [5]. Growers often use one application of glyphosate applied early (EPOST) or late postemergence (LPOST) or a sequential application of glyphosate applied EPOST and LPOST as the primary weed management strategy to control troublesome weeds in glyphosate-resistant corn [6-9].

It is important to control weeds as early as 2 weeks after emergence (WAE) and as late as 6 WAE to avoid yield loss in corn and other crops [10-12]. This wide range of time to control weeds to avoid yield losses necessitate glyphosate applications timings that are specific to weed populations and environmental conditions where 
glyphosate resistant cropping systems are being used [12]. Research has shown that a single-pass herbicide program with no residual activity can result in late emerging weeds and result in yield losses [13-18]. Other research has shown that it is possible to eliminate any yield loss due to weed interference with a single properly timed glyphosate application in glyphosate-resistant corn [19]. However, depending on weather conditions and weed species composition there is the potential for weeds to emerge after application. Control of late emerging weeds may increase corn yield, improve harvesting efficiency and reduce weed seed return to the soil.

Corn producers in Michigan and Ontario need more information to determine whether late emerging weeds have a negative impact on corn yield. The objective of this research was to determine the effect of late emerging weeds on the yield of glyphosate-resistant corn under Michigan and Ontario environmental conditions.

\section{MATERIALS AND METHODS}

\subsection{Study Establishment}

Fifteen field trials were established during 2009 to 2011 at various locations in Ontario, Canada and Michi- gan, USA as listed in Table 1. Trials were established as a randomized complete block design with four replications. Treatments included a weedy and weed-free control and corn were maintained weed-free with glyphosate (900 gae $\mathrm{ha}^{-1}$ ) up to the 2-, 4-, 6-, 8- or 10-leaf stage after which weeds were allowed to naturally infest the corn. Plots were $2 \mathrm{~m}$ wide and 8 or $10 \mathrm{~m}$ long. Glyphosateresistant corn hybrids were seeded at approximately 70,000 seeds $\cdot \mathrm{ha}^{-1}$ in rows that were spaced $76 \mathrm{~cm}$ apart at a depth of $5 \mathrm{~cm}$ on dates listed in Table 1.

Glyphosate was applied with a $\mathrm{CO}_{2}$-pressurized backpack sprayer equipped with ULD 120-02 flat fan nozzles (Hypro, New Brighton, MN) calibrated to deliver 200 $\mathrm{L} \cdot \mathrm{ha}^{-1}$ of water at $210 / 241 \mathrm{kPa}$ in Ontario. In Michigan, glyphosate was applied with a tractor-mounted compressed-air sprayer equipped with flat-fan nozzles (TeeJet $^{\circledR}$ XR 8003, Spraying Systems Co., Glendale Heights, IL) and calibrated to deliver $187 \mathrm{~L} \cdot \mathrm{ha}^{-1}$ at a pressure of $207 \mathrm{kPa}$.

\subsection{Data Collection}

Weed control was evaluated on a scale of $0 \%$ to $100 \%(0$ $=$ no weed control, and $100=$ complete weed control) 2 and 6 weeks after the last glyphosate application (WAT).

Table 1. Planting date, emergence date, and corn hybrids for fifteen field trials established during 2009 to 2011 at various locations in Ontario, Canada and Michigan, USA.

\begin{tabular}{|c|c|c|c|c|}
\hline Location & Year & Planting Date & Emergence Date & Corn Hybrid \\
\hline \multicolumn{5}{|l|}{ Environment 1} \\
\hline Exeter & 2009 & May 12 & May 25 & Pioneer $38 \mathrm{M} 58$ \\
\hline East Lansing, MI & 2010 & April 30 & - & DKC 46-61 \\
\hline \multirow[t]{2}{*}{ Ridgetown } & $2009 a$ & May 6 & May 22 & Pioneer $35 \mathrm{~F} 44$ \\
\hline & $2009 c$ & May 4 & May 22 & Pioneer 35F44 \\
\hline \multicolumn{5}{|l|}{ Environment 2} \\
\hline \multirow[t]{2}{*}{ Exeter } & 2010 & April 21 & - & DKC 46-07 \\
\hline & 2011 & May 13 & May 24 & DKC 46-07 \\
\hline Harrow & 2011 & June 1 & June 6 & DKC 61-21 \\
\hline Entrican, MI & 2010 & April 28 & - & DKC 46-61 \\
\hline East Lansing, MI & 2011 & May 10 & - & DKC 46-61 \\
\hline \multirow[t]{6}{*}{ Ridgetown } & $2009 b$ & May 6 & May 19 & Pioneer 35F44 \\
\hline & $2010 \mathrm{a}$ & May 5 & May 21 & DKC 50-45 \\
\hline & $2010 b$ & May 5 & May 23 & DKC 50-45 \\
\hline & $2010 \mathrm{c}$ & May 17 & May 24 & DKC 50-45 \\
\hline & $2011 \mathrm{a}$ & May 12 & May 23 & DKC 52-59 \\
\hline & $2011 b$ & May 12 & May 23 & DKC 52-59 \\
\hline
\end{tabular}


Weed biomass was taken and the number and species of weeds were recorded from two half-meter quadrats in each plot 6 WAT. Corn height from the soil surface to the upper most extended leaf was measured from ten randomly selected corn plants per plot 2 and 6 WAT. Corn was harvested in October/November using a plot combine and yields were adjusted to $15.5 \%$ seed moisture content.

\subsection{Statistical Analysis}

All data were subjected to analysis of variance. Tests were combined over locations and years and analyzed using the MIXED procedure of SAS (Ver. 9.2, SAS Institute Inc., Cary, NC). Variances were separated into the random effects of location (year and location), replication (at each location) and location by treatment. Herbicide treatment was considered the fixed effect. The significance of the random effects (location, replication and location by treatment) and their interaction with fixed effects was tested using the Z-test of the variance estimate. To ensure the assumptions (errors are independent, homogenous and normally distributed) of the variance analysis were met; residual plots were examined. Data were tested for normality using the Shapiro-Wilk statistic as generated by the UNIVARIATE procedure in SAS. If necessary, a transformation of the data (natural log, square root or arcsine square root) was applied and chosen based on the highest Shapiro-Wilk statistic generated. Means were separated using Fisher's protected LSD at $p$ $<0.05$. Data were pooled into environments based on the significance level of the treatment*year*location interaction.

\section{RESULTS AND DISCUSSION}

Data were separated into two environments based on the impact of treatment on corn yield. Environment 1 included Exeter 2009, East Lansing, MI 2010, Ridgetown 2009a, and Ridgetown 2009c and Environment 2 included Exeter 2010, Exeter 2011, Harrow 2011, Entrican, MI 2010, East Lansing, MI 2011, Ridgetown 2009b, Ridgetown 2010a-c, and Ridgetown 2011a-b.

\subsection{Weed Control}

The most prominent weeds were velvetleaf (ABUTH), redroot pigweed (AMARE), common ragweed (AMBEL), common lambsquarters (CHEAL) and green foxtail (SETVI).

At 2 weeks after the last application of glyphosate, there was no improvement in weed control when corn was kept weed-free later than 2, 2, 4, 2, and 6-leaf stage in environment 1 and 2, 4, 4, 10, and 6-leaf stage in environment 2 for ABUTH, AMARE, AMBEL, CHEAL, and SETVI, respectively (Tables 2 and 3).

At 6 weeks after the last application of glyphosate, there was no improvement in weed control when corn was kept weed-free later than 4, 4, 6, 6, and 8-leaf stage in environment 1 and 6,8,6,4, and 8-leaf stage in environment 2 for ABUTH, AMARE, AMBEL, CHEAL, and SETVI, respectively (Tables 2 and 3).

\subsection{Weed Biomass and Density}

There was improved weed control the longer corn was kept weed-free compared to weedy control. At 6 WAT, there were as much as $47 \%, 89 \%, 99 \%, 81 \%$, and $3 \%$

Table 2. Control of various weed species ( 2 and 6 WAT) after corn was maintained weeds free for different lengths of time in environment 1 (Exeter 2009, East Lansing 2010, Ridgetown 2009a, Ridgetown 2009c.).

\begin{tabular}{|c|c|c|c|c|c|c|c|c|c|c|}
\hline \multirow{4}{*}{ Treatment $^{\mathrm{z}}$} & \multicolumn{10}{|c|}{ Environment 1} \\
\hline & \multicolumn{10}{|c|}{ Weed Control (\%) } \\
\hline & \multicolumn{2}{|c|}{ ABUTH } & \multicolumn{2}{|c|}{ AMARE } & \multicolumn{2}{|c|}{ AMBEL } & \multicolumn{2}{|c|}{ CHEAL } & \multicolumn{2}{|c|}{ SETVI } \\
\hline & 2 WAT & 6 WAT & 2 WAT & 6 WAT & 2 WAT & $6 \mathrm{WAT}$ & 2 WAT & $6 \mathrm{WAT}$ & 2 WAT & 6 WAT \\
\hline Weedy Control & $0 \mathrm{~b}$ & $0 \mathrm{c}$ & $0 \mathrm{~b}$ & $0 \mathrm{c}$ & $0 \mathrm{c}$ & $0 \mathrm{~d}$ & $0 \mathrm{~b}$ & $0 \mathrm{~d}$ & $0 \mathrm{c}$ & $0 \mathrm{~d}$ \\
\hline Last glyphosate at $21 f$ & $100 \mathrm{a}$ & $65 \mathrm{~b}$ & $98 \mathrm{a}$ & $39 b$ & $81 b$ & $38 \mathrm{c}$ & $94 \mathrm{a}$ & $38 \mathrm{c}$ & $99 \mathrm{a}$ & $32 \mathrm{c}$ \\
\hline Last glyphosate at $41 \mathrm{f}$ & $100 \mathrm{a}$ & $100 \mathrm{a}$ & $99 \mathrm{a}$ & $93 a$ & $99 \mathrm{a}$ & $70 b$ & $92 \mathrm{a}$ & $76 b$ & $88 \mathrm{~b}$ & $38 \mathrm{c}$ \\
\hline Last glyphosate at 6lf & $100 \mathrm{a}$ & $100 \mathrm{a}$ & $99 \mathrm{a}$ & $99 \mathrm{a}$ & $98 \mathrm{a}$ & $90 \mathrm{a}$ & $97 \mathrm{a}$ & $88 \mathrm{ab}$ & $92 \mathrm{ab}$ & $70 \mathrm{~b}$ \\
\hline Last glyphosate at $81 \mathrm{f}$ & $100 \mathrm{a}$ & $98 \mathrm{a}$ & $100 \mathrm{a}$ & $100 \mathrm{a}$ & $98 \mathrm{a}$ & $92 \mathrm{a}$ & $97 \mathrm{a}$ & $93 \mathrm{a}$ & $94 \mathrm{a}$ & $79 \mathrm{ab}$ \\
\hline Last glyphosate at $101 \mathrm{f}$ & $100 \mathrm{a}$ & $100 \mathrm{a}$ & $100 \mathrm{a}$ & $100 \mathrm{a}$ & $100 \mathrm{a}$ & $100 \mathrm{a}$ & $100 \mathrm{a}$ & $100 \mathrm{a}$ & $98 \mathrm{a}$ & $97 \mathrm{a}$ \\
\hline Weed-Free Control & $100 \mathrm{a}$ & $100 \mathrm{a}$ & $100 \mathrm{a}$ & $100 \mathrm{a}$ & $100 \mathrm{a}$ & $100 \mathrm{a}$ & $100 \mathrm{a}$ & $100 \mathrm{a}$ & $100 \mathrm{a}$ & $100 \mathrm{a}$ \\
\hline
\end{tabular}

${ }^{\mathrm{z}}$ Glyphosate was applied postemergence at 900 gae $\cdot \mathrm{ha}^{-1}$. ${ }^{\mathrm{y}}$ Data were averaged for environments. Means followed by the same letter within a column are not significantly different according to Fisher's Protected LSD $(\mathrm{p}<0.05)$. 
Table 3. Control of various weed species ( 2 and 6 WAT) after corn was maintained weeds free for different lengths of time in environment 2 (Exeter 2010, Exeter 2011, Harrow 2011, Entrican 2010, East Lansing 2011, Ridgetown 2009b, Ridgetown 2010a-c, Ridgetown 2011a-b).

\begin{tabular}{|c|c|c|c|c|c|c|c|c|c|c|}
\hline \multirow{4}{*}{ Treatment $^{z}$} & \multicolumn{10}{|c|}{ Environment 2} \\
\hline & \multicolumn{10}{|c|}{ Weed control (\%) } \\
\hline & \multicolumn{2}{|c|}{ ABUTH } & \multicolumn{2}{|c|}{ AMARE } & \multicolumn{2}{|c|}{ AMBEL } & \multicolumn{2}{|c|}{ CHEAL } & \multicolumn{2}{|c|}{ SETVI } \\
\hline & 2 WAT & $6 \mathrm{WAT}$ & 2 WAT & 6 WAT & 2 WAT & 6 WAT & 2 WAT & 6 WAT & 2 WAT & 6 WAT \\
\hline Weedy control & $0 \mathrm{~b}$ & $0 \mathrm{~d}$ & $0 \mathrm{c}$ & $0 \mathrm{e}$ & $0 \mathrm{c}$ & $0 \mathrm{~d}$ & od & $0 \mathrm{c}$ & $0 \mathrm{~d}$ & $0 \mathrm{e}$ \\
\hline Last glyphosate at $21 \mathrm{f}$ & $95 \mathrm{a}$ & $65 \mathrm{c}$ & $92 b$ & $80 \mathrm{~d}$ & $94 \mathrm{~b}$ & $79 \mathrm{c}$ & $94 \mathrm{c}$ & $70 \mathrm{~b}$ & $91 \mathrm{c}$ & $72 d$ \\
\hline Last glyphosate at $41 \mathrm{f}$ & $94 a$ & $79 \mathrm{~b}$ & $97 \mathrm{a}$ & $87 \mathrm{~cd}$ & $97 \mathrm{a}$ & $88 b$ & $94 \mathrm{c}$ & $81 \mathrm{ab}$ & $94 \mathrm{bc}$ & $81 \mathrm{c}$ \\
\hline Last glyphosate at $61 \mathrm{f}$ & $95 \mathrm{a}$ & $92 \mathrm{a}$ & $97 \mathrm{a}$ & $92 \mathrm{bc}$ & $99 \mathrm{a}$ & $96 a$ & $96 \mathrm{bc}$ & $100 \mathrm{a}$ & $97 \mathrm{ab}$ & $90 \mathrm{~b}$ \\
\hline Last glyphosate at $81 \mathrm{f}$ & $95 \mathrm{a}$ & $96 a$ & $98 \mathrm{a}$ & $96 \mathrm{ab}$ & $100 \mathrm{a}$ & $98 \mathrm{a}$ & $96 \mathrm{bc}$ & $93 \mathrm{ab}$ & $99 \mathrm{a}$ & $96 \mathrm{ab}$ \\
\hline Last glyphosate at $101 \mathrm{f}$ & $100 \mathrm{a}$ & $99 \mathrm{a}$ & $99 a$ & $99 \mathrm{a}$ & $100 \mathrm{a}$ & $100 \mathrm{a}$ & $98 \mathrm{ab}$ & $98 \mathrm{a}$ & $99 a$ & $98 \mathrm{ab}$ \\
\hline Weed-free control & $100 \mathrm{a}$ & $100 \mathrm{a}$ & $100 \mathrm{a}$ & $100 \mathrm{a}$ & $100 \mathrm{a}$ & $100 \mathrm{a}$ & $100 \mathrm{a}$ & $100 \mathrm{a}$ & $100 \mathrm{a}$ & $100 \mathrm{a}$ \\
\hline
\end{tabular}

${ }^{\mathrm{z}}$ Glyphosate was applied postemergence at 900 gae $\cdot \mathrm{ha}^{-1} .{ }^{\mathrm{y}}$ Data were averaged for environments. Means followed by the same letter within a column are not significantly different according to Fisher's Protected LSD $(\mathrm{p}<0.05)$.

reduction in biomass of ABUTH, AMARE, AMBEL, CHEAL, and SETVI respectively compared to weedy control when corn was kept weed-free until the 2-leaf corn stage (Tables 4 and 5). At 6 weeks after the last application of glyphosate, there was no decrease in weed biomass when corn was kept weed-free later than 4, 4, 4, 4, and 6-leaf corn stage under both environments for ABUTH, AMARE, AMBEL, CHEAL, and SETVI, respectively (Tables 4 and 5).

At 6 WAT, there were as much as $60 \%, 70 \%, 90 \%$, $49 \%$, and $22 \%$ reduction in density of ABUTH, AMARE, AMBEL, CHEAL, and SETVI respectively compared to weedy control when corn was kept weed-free until the 2-leaf corn stage (Tables 4 and 5). There was no decrease in weed density when corn was kept weed-free later than 2, 2, 4, 6, and 8-leaf stage under both environments for ABUTH, AMARE, AMBEL, CHEAL, and SETVI, respectively (Tables 4 and 5).

Weeds emerging after the 6th leaf stage of corn were small (low biomass/seedlings) and most likely did not reach reproductive maturity.In other studies, Stewart et al. [8] found 91\% - 100\% control of AMARE, 85\% - 100\% of CHEAL and $78 \%$ - 97\% control of SETVI with a single POST application of glyphosate at 3 - 4 leaf corn. Another study [20] found that ABUTH, AMARE, AMBEL, CHEAL, and annual grasses were controlled 38\% $93 \%, 93 \%, 99 \%-100 \%, 71 \%-100 \%, 30 \%-98 \%$ at $3-$ 4 leaf stage and 98\% - 99\%, 100\%, 78\% - 100\%, 71\% $98 \%$, and $91 \%-100 \%$ at $7-8$ leaf stage in glyphosate resistant corn, respectively. Thomas et al. [21] reported $96 \%-100 \%$ control of CHEAL, $100 \%$ control of AMBEL, $66 \%$ - 91\% control of IPOSP (morningglory), 72\% - 98\% control of ELEIN (goosegrass) and 79\% - 96\% control of DIGSA (large crabgrass) with glyphosate POST applications at 4 - 6 leaf stage in glyphosate resistant corn.

\subsection{Corn Height and Yield}

Corn height was as much as $14 \%$ and $16 \%$ taller at 2 WAT and $16 \%$ and $31 \%$ higher at 6 WAT compared to the weedy control with glyphosate treatments in environment 1 and 2, respectively (Table 6). There was no decrease in corn height if weeds were allowed to emerge after the 2 leaf stage of corn at 2 or 6 WAT (Table 6). There were no differences in corn height due to the length of time the corn was kept weed-free or between environments (Table 6).

In Environment 1 (4/15 sites) corn had to be kept weed-free up to the 4-leaf stage to prevent any yield loss due to late-emerging weeds. There was no yield loss in corn if weeds were allowed to emerge after the 4-leaf stage of corn (Table 6). Yield was $40 \%$ higher than weedy control when corn was kept weed free until the 2-leaf corn stage. Similarly, yield was as much as $52 \%$ higher than the weedy control when the last glyphosate treatment was applied at 4 - 10 leaf corn stage (Table 6).

In Environment 2 (11/15 sites) corn had to be kept weed-free up to the 2-leaf stage to prevent any yield loss due to late-emerging weeds. There was no yield loss in corn if weeds were allowed to emerge after the 2-leaf stage of the corn (Table 6). Yield was as much as 53\% higher than weedy control when the last glyphosate treatment was applied at 2 - 10 leaf corn stage (Table 6). While weeds which emerged after various corn leaf stages did not necessarily impact yield, it is probable that 
Table 4. Aboveground biomass and density of various weed species (6 WAT) after corn was maintained weeds free for different lengths of time in environment 1 (Exeter 2009, East Lansing 2010, Ridgetown 2009a, Ridgetown 2009c).

\begin{tabular}{|c|c|c|c|c|c|c|c|c|c|c|}
\hline \multirow{4}{*}{ Treatment $^{z}$} & \multicolumn{10}{|c|}{ Environment 1} \\
\hline & \multicolumn{2}{|c|}{ ABUTH } & \multicolumn{2}{|c|}{ AMARE } & \multicolumn{2}{|c|}{ AMBEL } & \multicolumn{2}{|c|}{ CHEAL } & \multicolumn{2}{|c|}{ SETVI } \\
\hline & Biomass & Density & Biomass & Density & Biomass & Density & Biomass & Density & Biomass & Density \\
\hline & $\mathrm{g} / \mathrm{m}^{2}$ & no. $/ \mathrm{m}^{2}$ & $\mathrm{~g} / \mathrm{m}^{2}$ & no. $/ \mathrm{m}^{2}$ & $\mathrm{~g} / \mathrm{m}^{2}$ & no. $/ \mathrm{m}^{2}$ & $\mathrm{~g} / \mathrm{m}^{2}$ & no. $/ \mathrm{m}^{2}$ & $\mathrm{~g} / \mathrm{m}^{2}$ & no. $/ \mathrm{m}^{2}$ \\
\hline Weedy control & $2.9 \mathrm{a}$ & $4 a$ & $9.8 \mathrm{a}$ & $3 a$ & $82.3 \mathrm{a}$ & $20 \mathrm{a}$ & $193.1 \mathrm{a}$ & $34 \mathrm{a}$ & $17.3 \mathrm{ab}$ & $25 \mathrm{a}$ \\
\hline Last glyphosate at $21 \mathrm{f}$ & $2.0 \mathrm{a}$ & $2 \mathrm{a}$ & $14.6 \mathrm{a}$ & $5 \mathrm{a}$ & $18.3 \mathrm{~b}$ & $8 b$ & $49.6 \mathrm{~b}$ & $25 \mathrm{abc}$ & $24.4 \mathrm{a}$ & $41 \mathrm{a}$ \\
\hline Last glyphosate at $41 \mathrm{f}$ & $1.6 \mathrm{a}$ & $3 a$ & $0.3 \mathrm{~b}$ & $2 \mathrm{a}$ & $0.3 \mathrm{c}$ & $2 b c$ & $9.6 \mathrm{c}$ & $29 \mathrm{ab}$ & $13.9 \mathrm{ab}$ & $22 \mathrm{a}$ \\
\hline Last glyphosate at $61 \mathrm{f}$ & $0.1 \mathrm{a}$ & $1 \mathrm{a}$ & $0.2 \mathrm{~b}$ & $1 \mathrm{a}$ & $5.2 \mathrm{c}$ & $1 b c$ & $0.5 \mathrm{c}$ & $12 \mathrm{bcd}$ & $2.5 \mathrm{~b}$ & $43 a$ \\
\hline Last glyphosate at $81 \mathrm{f}$ & $0.2 \mathrm{a}$ & $3 a$ & $0 \mathrm{~b}$ & $0 \mathrm{a}$ & $0.2 \mathrm{c}$ & $1 b c$ & $0.6 \mathrm{c}$ & $8 \mathrm{~cd}$ & $1.7 \mathrm{~b}$ & $35 \mathrm{a}$ \\
\hline Last glyphosate at $101 \mathrm{f}$ & $0 \mathrm{a}$ & $0 \mathrm{a}$ & $0 \mathrm{~b}$ & $0 \mathrm{a}$ & $0 \mathrm{c}$ & $0 \mathrm{c}$ & $0 \mathrm{c}$ & 0 & $0.1 \mathrm{~b}$ & $13 \mathrm{a}$ \\
\hline Weed-free control & $0 \mathrm{a}$ & $0 \mathrm{a}$ & $0 \mathrm{~b}$ & $0 \mathrm{a}$ & $0 \mathrm{c}$ & $0 \mathrm{c}$ & $0 \mathrm{c}$ & $0 \mathrm{~d}$ & $0 \mathrm{~b}$ & $0 \mathrm{a}$ \\
\hline
\end{tabular}

${ }^{\mathrm{z}}$ Glyphosate was applied postemergence at 900 gae $\cdot \mathrm{ha}^{-1}$. ${ }^{\mathrm{y}}$ Data were averaged for environments. Means followed by the same letter within a column are not significantly different according to Fisher's Protected LSD $(\mathrm{p}<0.05)$.

Table 5. Aboveground biomass and density of various weed species (6 WAT) after corn was maintained weeds free for different lengths of time in environment 2 (Exeter 2010, Exeter 2011, Harrow 2011, East Lansing 2010, East Lansing 2011, Ridgetown 2009b, Ridgetown 2010a-c, Ridgetown 2011a-b).

\begin{tabular}{|c|c|c|c|c|c|c|c|c|c|c|}
\hline \multirow{4}{*}{ Treatment $^{\mathrm{z}}$} & \multicolumn{10}{|c|}{ Environment 2} \\
\hline & \multicolumn{2}{|c|}{ ABUTH } & \multicolumn{2}{|c|}{ AMARE } & \multicolumn{2}{|c|}{ AMBEL } & \multicolumn{2}{|c|}{ CHEAL } & \multicolumn{2}{|c|}{ SETVI } \\
\hline & Biomass & Density & Biomass & Density & Biomass & Density & Biomass & Density & Biomass & Density \\
\hline & $\mathrm{g} / \mathrm{m}^{2}$ & no. $/ \mathrm{m}^{2}$ & $\mathrm{~g} / \mathrm{m}^{2}$ & no. $/ \mathrm{m}^{2}$ & $\mathrm{~g} / \mathrm{m}^{2}$ & no. $/ \mathrm{m}^{2}$ & $\mathrm{~g} / \mathrm{m}^{2}$ & no. $/ \mathrm{m}^{2}$ & $\mathrm{~g} / \mathrm{m}^{2}$ & no. $/ \mathrm{m}^{2}$ \\
\hline Weedy control & $9.3 \mathrm{a}$ & $5 \mathrm{a}$ & $70.6 \mathrm{a}$ & $27 \mathrm{a}$ & $89.0 \mathrm{a}$ & $10 \mathrm{a}$ & $77.1 \mathrm{a}$ & $49 \mathrm{a}$ & $23.3 \mathrm{a}$ & $18 \mathrm{a}$ \\
\hline Last glyphosate at 2 lf & $4.9 \mathrm{ab}$ & $2 b$ & $7.6 \mathrm{~b}$ & $8 \mathrm{~b}$ & $1.3 \mathrm{~b}$ & $1 b$ & $14.9 \mathrm{~b}$ & $25 \mathrm{ab}$ & $22.7 \mathrm{a}$ & $14 \mathrm{ab}$ \\
\hline Last glyphosate at $41 \mathrm{f}$ & $1.7 \mathrm{~b}$ & $2 b$ & $1.5 \mathrm{~b}$ & $6 \mathrm{~b}$ & $0.1 \mathrm{~b}$ & $1 b$ & $8.3 b$ & $24 \mathrm{ab}$ & $9.5 \mathrm{ab}$ & $10 \mathrm{ab}$ \\
\hline Last glyphosate at 6lf & $1.4 \mathrm{~b}$ & $1 b$ & $0 \mathrm{~b}$ & $2 b$ & $0 \mathrm{~b}$ & $0 \mathrm{~b}$ & $2.2 \mathrm{~b}$ & $20 \mathrm{~b}$ & $2.9 \mathrm{~b}$ & $6 a b$ \\
\hline Last glyphosate at $81 \mathrm{f}$ & $0 \mathrm{~b}$ & $\mathrm{Ob}$ & $0 \mathrm{~b}$ & $0 \mathrm{~b}$ & $0.1 \mathrm{~b}$ & $1 b$ & $1.1 \mathrm{~b}$ & $14 \mathrm{~b}$ & $0.4 \mathrm{~b}$ & $3 b$ \\
\hline Last glyphosate at $101 \mathrm{f}$ & $0 \mathrm{~b}$ & $0 \mathrm{~b}$ & $0 \mathrm{~b}$ & $0 \mathrm{~b}$ & $0 \mathrm{~b}$ & $0 \mathrm{~b}$ & $0.3 b$ & $1 b$ & $0.4 \mathrm{~b}$ & $2 b$ \\
\hline Weed-free control & $0 \mathrm{~b}$ & $0 \mathrm{~b}$ & $0 \mathrm{~b}$ & $0 \mathrm{~b}$ & $0 \mathrm{~b}$ & $0 \mathrm{~b}$ & $0 \mathrm{~b}$ & $0 \mathrm{~b}$ & $0 \mathrm{~b}$ & $0 \mathrm{~b}$ \\
\hline
\end{tabular}

${ }^{\mathrm{z}}$ Glyphosate was applied postemergence at 900 gae $\cdot \mathrm{ha}^{-1}$. ${ }^{\mathrm{y}}$ Data were averaged for environments. Means followed by the same letter within a column are not significantly different according to Fisher's Protected LSD $(\mathrm{p}<0.05)$.

weed seeds were added to the soil seed bank for weeds emerging after the 2- and 4-leaf stage of corn (supported by visual ratings; data not shown).

In other studies, Ritchie et al. [22] found that a single application of glyphosate at 3-leaf corn stage prevented yield losses in corn. In north central USA, Gower et al. [23] found a glyphosate application at 4-leaf stage was generally needed to avoid yield losses in corn. In northeastern USA Cox et al. [24] found that a glyphosate application at 3 - 4 leaf corn stage is sufficient to avoid yield losses in glyphosate-resistant corn. Another study, in southwestern Ontario, Canada [20] found that there was no yield loss with a single application of glyphosate at 3 - 4 leaf stage but there was as much as 19\% yield loss when glyphosate was applied at 7 - 8 leaf stage in glyphosate-resistant corn. Other researchers have reported that depending on environmental conditions corn needs to be kept weed-free from the 3 - 14 leaf stage to avoid yield losses due to weed interference [23,25-27].

\section{CONCLUSION}

Based on these results, there is improved weed control with each additional application of glyphosate. For most 
Table 6. Effect of late emerging weeds on height and yield of corn in fifteen field trials established during 2009 to 2011 at various environments in Ontario, Canada and Michigan, USA. Means with the same letters within a columnare not significantly different at $P$ $<0.05$.,y

\begin{tabular}{|c|c|c|c|c|c|c|}
\hline \multirow{3}{*}{ Treatment $^{\mathrm{x}}$} & \multicolumn{4}{|c|}{ Corn height $(\mathrm{cm})$} & \multicolumn{2}{|c|}{ Yield $\left(\mathrm{t} \cdot \mathrm{ha}^{-1}\right)$} \\
\hline & \multicolumn{2}{|c|}{ Environment 1} & \multicolumn{2}{|c|}{ Environment 2} & \multirow[t]{2}{*}{ Environment 1} & \multirow[t]{2}{*}{ Environment 2} \\
\hline & 2 WAT & 6 WAT & 2 WAT & 6 WAT & & \\
\hline Weedy control & $159 b$ & $219 b$ & $150 \mathrm{~b}$ & $206 b$ & $6.1 \mathrm{c}$ & $7.1 \mathrm{~b}$ \\
\hline Last glyphosate at $21 \mathrm{f}$ & $175 a$ & $244 a$ & $175 \mathrm{a}$ & $238 \mathrm{a}$ & $10.1 \mathrm{~b}$ & $12.8 \mathrm{a}$ \\
\hline Last glyphosate at $41 \mathrm{f}$ & $179 \mathrm{a}$ & $256 a$ & $178 \mathrm{a}$ & $300 \mathrm{a}$ & $12.1 \mathrm{a}$ & $12.8 \mathrm{a}$ \\
\hline Last glyphosate at $61 \mathrm{f}$ & $182 \mathrm{a}$ & $261 \mathrm{a}$ & $179 a$ & $243 a$ & $12.6 \mathrm{a}$ & $13.2 \mathrm{a}$ \\
\hline Last glyphosate at $81 \mathrm{f}$ & $184 \mathrm{a}$ & $257 \mathrm{a}$ & $178 \mathrm{a}$ & $243 \mathrm{a}$ & $12.7 \mathrm{a}$ & $13.3 \mathrm{a}$ \\
\hline Last glyphosate at $101 \mathrm{f}$ & $182 \mathrm{a}$ & $255 \mathrm{a}$ & $177 \mathrm{a}$ & $238 \mathrm{a}$ & $12.6 \mathrm{a}$ & $13.3 \mathrm{a}$ \\
\hline Weed-free control & $180 \mathrm{a}$ & $260 \mathrm{a}$ & $177 \mathrm{a}$ & $237 \mathrm{a}$ & $12.6 \mathrm{a}$ & $13.4 \mathrm{a}$ \\
\hline
\end{tabular}

${ }^{\mathrm{z} E}$ Environment 1 = Exeter 2009, East Lansing 2010, Ridgetown 2009a, Ridgetown 2009c. ${ }^{\mathrm{y}}$ Environment 2 = Exeter 2010, Exeter 2011, Harrow 2011, Entrican2010, East Lansing 2011, Ridgetown 2009b, Ridgetown 2010a-c, Ridgetown $2011 \mathrm{a}-\mathrm{b}$. ${ }^{\mathrm{x}}$ Glyphosate was applied postemergence at 900 gae-ha ${ }^{-1}$.

weeds evaluated, there is no improvement in weed control when corn is kept weed-free until the 6-leaf stage of corn. Corn must be maintained weed free up to the 4-leaf stage. Weeds emerging after the 4-leaf stage do not influence corn yield. There were no differences among corn height for any treatments or between environments. Weeds emerging after the 6-leaf corn stage are less likely to reach reproductive maturity and contribute to the seed bank.

\section{ACKNOWLEDGEMENTS}

The authors would like to acknowledge Lynette Brown, Andrew Chomas, Todd Cowan, Chris Kramer and Christy Shropshire for their expertise and technical assistance in these studies.

\section{REFERENCES}

[1] Kulasekera, K. (2012a) Grain corn: Area and production, by county, 2011. http://www.omafra.gov.on.ca/english/stats/crops/ctygrcor $\underline{\mathrm{n} 11 . \mathrm{htm}}$

[2] Kulasekera, K. (2012b) Statistical summary of Ontario agriculture.

http://www.omafra.gov.on.ca/english/stats/agriculture su mmary.htm\#commodities

[3] Ontario Ministry of Agriculture, Food and Rural Affairs (2012) Guide to weed control, publication 75. OMAFRA, Toronto, 379.

[4] Sikkema, P.H., Robinson, D.E., Tardif, F.J., Lawton, M.B. and Soltani, N. (2013) Discovery of glyphosate-resistant weeds in Ontario, Canada-Distribution plus control. Global Herbicide Resistant Challenge Conference, Perth, 18-22 February 2013, 96.

[5] Sikkema, P.H. and Soltani, N. (2007) Herbicide-resistant crops in eastern Canada. In: Gulden, R.H. and Swanton,
C.J., Eds., The First Decade of Herbicide-Resistant Crops in Canada. Topics in Canadian Weed Science, 4, Sainte Anne de Bellevue, 3-13.

[6] Barnes, J.W. and Oliver, L.R. (2004) Cloransulam antagonizes annual grass control with aryloxyphenoxypropionate graminicides but not cyclohexanediones. Weed Technology, 18, 763-772. doi:10.1614/WT-03-181R

[7] Nurse, R.E., Swanton, C.J., Tardif, F. and Sikkema, P.H. (2006) Weed control and yield are improved when glyphosate is preceded by a residual herbicide in glyphosatetolerant maize (Zea mays). Crop Protection, 25, 1174 1179. doi:10.1016/i.cropro.2006.02.015

[8] Stewart, C.L., Soltani, N., Nurse, R.E., Hamill, A.S. and Sikkema P.H. (2012) Precipitation influences pre- and post-emergence herbicide efficacy in corn. American Journal of Plant Sciences, 3, 1193-1204. doi:10.4236/ajps.2012.39145

[9] Young, B.G. (2006) Changes in herbicide use patterns and production practices resulting from glyphosate-resistant crops. Weed Technology, 20, 301-307. doi:10.1614/WT-04-189.1

[10] Baysinger J.A. and Sims, B.D. (1992) Giant ragweed (Ambrosia trifida) interference in soybean (Glycine max). Weed Science, 39, 358-362.

[11] Fellows, G.M. and Roeth, F.W. (1992) Shattercane (Sorghum bicolor) interference in soybean (Glycine max). Weed Science, 40, 68-73.

[12] Mulugeta, D. and Boerboom, C.M. (2000) Critical time of weed removal in glyphosate-resistant Glycine max. Weed Science, 48, 35-42. doi:10.1614/0043-1745(2000)048[0035:CTOWRI]2.0.C $\underline{\mathrm{O} ; 2}$

[13] Gonzini, L.C., Hart, S.E. and Wax, L.M. (1999) Herbicide combinations for weed management in glyphosateresistant soybean (Glycine max). Weed Technology, 13, 354-360. 
[14] Gower, S.A., Loux, M.M., Cardina, J. and Harrison, S.K. (2002) Effect of planting date, residual herbicide, and postemergence application timing on weed control and grain yield in glyphosate-resistant corn (Zea mays). Weed Technology, 16, 488-494. doi:10.1614/0890-037X(2002)016[0488:EOPDRH]2.0.C $\underline{\mathrm{O} ; 2}$

[15] Hartzler, B. (1996) Is one-pass weed control a realistic goal? Department of Agronomy, Iowa State University Extension Agronomy, 3.

[16] Loux, M.M., Dobbels, A.F., Johnson, W.G., Nice, G.R.W., Bauman, T.T. and Stachler, J.M. (2008) Weed control guide for Ohio and Indiana. Ohio State University Extension Bulletin 789/Purdue Extension Pub No. WS16, 201.

[17] Nurse, R.E., Hamill, A.S., Swanton, C.J., Tardif, F.J., Deen, W. and Sikkema, P.H. (2007) Is the application of a residual herbicide required prior to glyphosate application in no-till glyphosate-tolerant soybean (Glycine max)? Crop Protection, 26, 484-489. doi:10.1016/j.cropro.2006.04.018

[18] Stewart, C.L., Nurse, R.E., Hamill, A.S. and Sikkema, P.H. (2010) Environment and soil conditions influence pre- and post-emergence herbicide efficacy in soybean. Weed Technology, 24, 234-243. doi:10.1614/WT-09-009.1

[19] Boerboom, C. (2003) Economics of residual herbicides in Roundup Ready crops. http://www.soils.wisc.edu/extension/FAPM/2003proceedi ngs/Boerboom-1.pdf

[20] Soltani, N., Stewart, C.L., Nurse, R.E., Van Eerd, L.L., Vyn, R.J. and Sikkema, P.H. (2012) Weed control, envi- ronmental impact and profitability of weed management strategies in glyphosate-tolerant Corn. American Journal of Plant Sciences, 3, 1594-1607.

[21] Thomas, W.E., Burke, I.C. and Wilcut, J.W. (2004). Weed management in glyphosate-resistant corn with glyphosate, halosulfuron, and mesotrione. Weed Technology, 18, 826834.

[22] Ritchie, S.W., Hanway, J.J. and Benson, G.O. (1993) How a corn plant develops. Iowa State University of Science and Technology Cooperative Extension Service, Ames.

[23] Gower, S.A., Loux, M.M., Cardina, J., Harrison, S.K., Sprankle, P.L., et al. (2003) Effect of postemergence glyphosate application timing on weed control and grain yield in glyphosate-resistance corn: Results of a 2 year multistate study. Weed Technology, 17, 821-828.

[24] Cox, W.J., Hahn R.R. and Stachowski, P.J. (2006) Time of weed removal with glyphosate affects corn growth and yield components. Agronomy Journal, 98, 349-353.

[25] Dalley, C.D., Kells, J.J. and Renner. K.A. (2004) Effect of glyphosate application timing and row spacing on corn and soybean yields. Weed Technology, 18, 165-176.

[26] Hall, M.R., Swanton, C.J. and Anderson, G.J. (1992) The critical period of weed control in grain corn. Weed Science, 40, 441-447.

[27] Tharp, B.E. and Kells, J.J. (1999). Influence of herbicide application rate, timing, and interrow cultivation on weed control and corn (Zea mays) yield in glufosinate-resistant and glyphosate-resistant corn. Weed Technology, 13, 807 813. 